\title{
TANNINS IN BACCHARIS DRACUNCULIFOLIA (ASTERACEAE): EFFECTS OF SEASONALITY, WATER AVAILABILITY AND PLANT SEX
}

\author{
Mário M. Espírito-Santo ${ }^{1}$ \\ G. Wilson Fernandes ${ }^{1}$ \\ Luciana R. Allain' \\ Ticiana R. F. Reis ${ }^{1}$
}

Recebido em 29/12/1998. Aceito em 18/05/1999

\begin{abstract}
Tannins in Baccharis dracunculifolia (Asteraceae): effects of seasonality, water availability and plant sex). Several ecological, genetic, and environmental factors are known to influence tannin concentration in plant tissues. In this study, the effects of seasonality, water availability, and sex of the plant on tannin concentration in the dioecious shrub Baccharis dracunculifolia were assessed. The effects of water availability on plant shoot growth and its relationship to tannin concentration were also experimentally evaluated. Tannins occurred in $B$. dracunculifolia from November to May, peaking during the summer (December to March). However, no relationship between tannin concentration, rainfall and temperature was found. No difference in tannin concentration and shoot growth was found between plants in the irrigated and control treatments, this suggesting that tannin production was affected by factors other than water availability, such as light intensity or plant phenology. There was a negative relationship between tannin concentration and shoot growth, possibly due to a trade-off between these metabolic activities. Plant gender did not influence tannin concentration and shoot growth, indicating that $B$. dracunculifolia did not show a differential resource allocation between male and female individuals.
\end{abstract}

Key words - tannins, Baccharis dracunculifolia, irrigation, gender, phenology

RESUMO - (Taninos em Baccharis dracunculifolia (Asteraceae): efeitos da sazonalidade, disponibilidade de água e sexo da planta). Vários fatores ecológicos, genéticos e ambientais podem influenciar a concentração de taninos em tecidos de uma planta. Neste estudo, os efeitos da sazonalidade, disponibilidade de água e sexo da planta sobre a concentração de taninos no arbusto dióico Baccharis dracunculifolia foram avaliados. Também foram verificados os efeitos da disponibilidade de água sobre o crescimento de ramos da planta e a relação com a concentração de taninos. Os indivíduos de $B$. dracunculifolia produziram taninos de novembro a maio, apresentando maiores concentrações durante o verão (dezembro a março). Entretanto, não foram encontradas relações entre a concentração de taninos e a precipitação e a temperatura, assim como também nâo foram observadas diferenças na concentração de taninos e crescimento de ramos entre plantas irrigadas e controle, sugerindo que a produção dessas substâncias seja afetada por outros fatores, como intensidade de luz ou fenologia da planta. Houve relação negativa entre a concentração de taninos e o crescimento de ramos, possivelmente em virtude de um "trade-off" entre estas atividades metabólicas. Não foram observadas diferenças intersexuais na concentração de taninos e crescimento de ramos, indicando que $B$. dracunculifolia não apresenta distribuição diferencial de recursos entre indivíduos masculinos e femininos.

Palavras-chave - taninos, Baccharis dracunculifolia, irrigação, sexo, fenologia

1 Laboratório de Ecologia Evolutiva de Herbívoros Tropicais, ICB, Universidade Federal de Minas Gerais, C. Postal 486, CEP 30161-970, Belo Horizonte, MG, Brasil 


\section{Introduction}

Tannins are carbon-based polyphenolic compounds produced by the secondary metabolism of plants (Rhoades \& Cates 1976). These metabolites are often described as water-soluble and capable of precipitating a variety of proteins (Swain 1979). Tannins are thought to confer structural rigidity to the plant as well as protection against dehydration and rotting (Esau 1959; Fahn 1990; Rozema et al. 1997). These secondary compounds also play an important role in plant defense against pathogens and herbivores, as they reduce nutrient digestibility after ingestion (Feeny 1970; Salatino et al. 1993). The effects of tannins in herbivores include a decrease in feeding range, a slowdown in development, and an increase in mortality rates (Faeth 1992). The concentration of tannins in plant tissue may be determined by many factors, such as environmental conditions (i.e., water and nutrient availability; Herms \& Mattson 1992; Shure et al. 1998) and parameters related to the plant, mainly plant phenology (Feeny 1970; Espírito-Santo \& Fernandes 1998), sex (Jing \& Coley 1990; Herms \& Mattson 1992), and age (Coley \& Barone 1996).

Plant resource allocation to growth or reproduction may drastically influence the phenolic content in plant tissue, since these activities affect the plant carbon-nitrogen balance (Bryant et al. 1983; Herms \& Mattson 1992). Therefore, differences in plant tannin concentration are expected during the growing, reproductive, and vegetative stages. Seasonal variations are also expected due to the different availability of water and nutrients during the dry and wet seasons (Shure et al. 1998). When conditions are favorable, plants preferentially allocate carbon to growth. On the other hand, when light, water, or nutrients are in low availability, carbon will often accumulate, and be used for the synthesis of secondary compounds, such as tannins (Bryant et al. 1983; Herms \& Mattson 1992).

Many species of dioecious plants may present sex-related differences in carbon-based defenses, due to a different allocation of the available resources (Krischik \& Denno 1990). Females generally have a higher investment in reproduction than males, channelling a greater amount of nutrients to the maturation of reproductive structures (Herms \& Mattson 1992). Therefore, females have relatively more carbon accumulated in their vegetative tissues (a higher $\mathrm{C} / \mathrm{N}$ ratio) than males do. This excess is processed by the secondary metabolism to produce carbon-based secondary metabolites, such as tannins, and other phenolic compounds (Herms \& Mattson 1992). Hence, these compounds may present contrasting concentrations in different sexes of the plant.

In this study, tannin concentration was assessed in leaves of Baccharis dracunculifolia De Candole (Asteraceae), a widespread dioecious perennial shrub occurring in Southwestern and Southern Brazil, Argentina, Paraguay, Uruguay and Bolivia. The following questions were approached: 1) Is there a seasonal variation in tannin concentration in B. dracunculifolia? 2) What are the effects of irrigation on shoot growth and tannin concentration in B. dracunculifolia? 3) Is there a relationship between shoot growth and tannin concentration? 4) Are there differences in tannin concentration between male and female individuals of $B$. dracunculifolia?

\section{Materials and methods}

Study area - The study was performed on the Campus of the "Universidade Federal de Minas Gerais”, Belo Horizonte, Brazil (19³0'S, $44^{\circ} 00^{\prime} \mathrm{W}$ ), at $805 \mathrm{~m}$ above sea level. The average annual temperature of the study site varies from 18 to $20^{\circ} \mathrm{C}$, and the average annual rainfall is $1,500 \mathrm{~mm}$ (Espírito-Santo \& Fernandes 1998). The vegetation is extremely heterogeneous and disturbed, being composed of natural, introduced, ornamental and fruit-bearing species. The adjacent native vegetation is composed of forest and cerrado (savanna) species (Ferrari 1977). The study plants were all located in a $2 \mathrm{ha}$ area at an early successional stage, with a predominance of B. dracunculifolia, two other species of Baccharis, grasses, herbaceous plants, and shrubby leguminous species (Araújo et al. 1995).

Seasonal variation in tannin concentration To verify the seasonal variation in the amount of 
tannin produced by $B$. dracunculifolia, 10 plants were randomly assigned (five males and five females) in the field. Tannin concentration in plant leaves was measured monthly from November/ 1993 to October/1994, using the radial diffusion method. In this method, tannins in plant extracts are determined by the reaction with Bovine Serum Albumin, and quantifying the precipitated complex (mg/g leaf tissue) (Hagerman 1987). The effects of the monthly average temperature and average rainfall on tannin concentration throughout the year were evaluated using linear regression analyses (Zar 1996).

Water availability - The effects of water availability on tannin concentration in leaves of $B$. dracunculifolia were assessed by an irrigation experiment during August/1994, in the middle of the dry season. Twenty individuals were randomly marked and grouped into two treatments: control and irrigated, each consisting of five male and five female plants. Each plant of the irrigated treatment was watered with ten liters of water every other day from the $15^{\text {th }}$ to the $29^{\text {th }}$ August. This experiment would emulate the effects of rainy/dry periods, allowing us to directly verify the influence of water availability on tannin production in the field. Tannin concentration was measured before the beginning of irrigation, and on the $9^{\text {th }}, 16^{\text {th }}, 23^{\text {rd }}$, $39^{\text {th }}, 47^{\text {th }}$, and $69^{\text {th }}$ days, after the end of the irrigation experiment. Differences in tannin concentration between treatments at each time interval were tested using the Mann-Whitney U test, as the data were not normally distributed (Zar 1996). To evaluate the possible effects of irrigation on plant growth, 10 shoots were randomly marked on each plant in both treatments. Shoots were measured at the same intervals used to assess tannin concentration, and the relative growth rate was calculated by

$$
\mathrm{T}_{\mathrm{c}}=\left(\mathrm{C}_{\mathrm{f}}-\mathrm{C}_{\mathrm{i}}\right) / \mathrm{C}_{\mathrm{i}}
$$

where $T_{c}=$ relative growth rate; $C_{i}=$ initial length; and $\mathrm{C}_{\mathrm{f}}=$ final length. Differences in growth rates between treatments were compared at each time interval, by the Mann-Whitney U test, as the data were not normally distributed (Zar 1996). The relationship between average shoot growth per plant and plant tannin concentration was analysed for each treatment, and at each time interval using Spearman correlations (Zar 1996).

Gender differences - To observe whether differences in tannin concentration were influenced by the sex of plant, the data obtained during the study of seasonal variation were compared between male and female plants. Differences in tannin concentration were compared using a Student's t test (Zar 1996).

\section{Results and discussion}

Seasonal variation in tannin concentration Tannin concentration in B. dracunculifolia showed a pronounced variation during the study period (Fig. 1a). Tannin concentration was higher from December/1993 to April/1994, but plants also produced tannins in November/1993 and May/ 1994. Tannin concentration in the other months was below the limit of detection of the radial diffusion method $(0.025 \mathrm{mg} / \mathrm{g})$. Although tannin production was higher during the wet summer, no significant relationship between tannin concentration and temperature were found $\left(\mathrm{r}^{2}=0.10\right.$, $\mathrm{p}>0.05, \mathrm{~F}=0.78, \mathrm{y}=0.093+0.01 \mathrm{x}, \mathrm{n}=120$ ), and rainfall $\left(\mathrm{r}^{2}=0.13, \mathrm{p}>0.05, \mathrm{~F}=1.62, \mathrm{y}=-1.43\right.$ $+0.78 \mathrm{x}, \mathrm{n}=120$ ) (Fig. 1a and 1b).

Seasonal variation in the concentration of phenolic compounds have been reported in many studies (Feeny 1970; Shure et al. 1998). These variations are often correlated with plant phenology (Sagers \& Coley 1995; Espírito-Santo \& Fernandes 1998) or environmental conditions (Bryant et al. 1983; Herms \& Mattson 1992; Shure et al. 1998). In this study, an increased concentration of tannins was found during the summer, when water and probably light availability were higher. Mole et al. (1988) reported that plants receiving greater rates of photosynthetically active radiation may accumulate and store poorly translocatable phenolic compounds, such as condensed tannins. Tannins are important filters of solar UV-B radiation, and its enhanced concentration during the summer may protect the plants against several harmful morphogenetic effects produced by excessive exposure to this radiation (Rozema et al. 1997). Consequently, it 

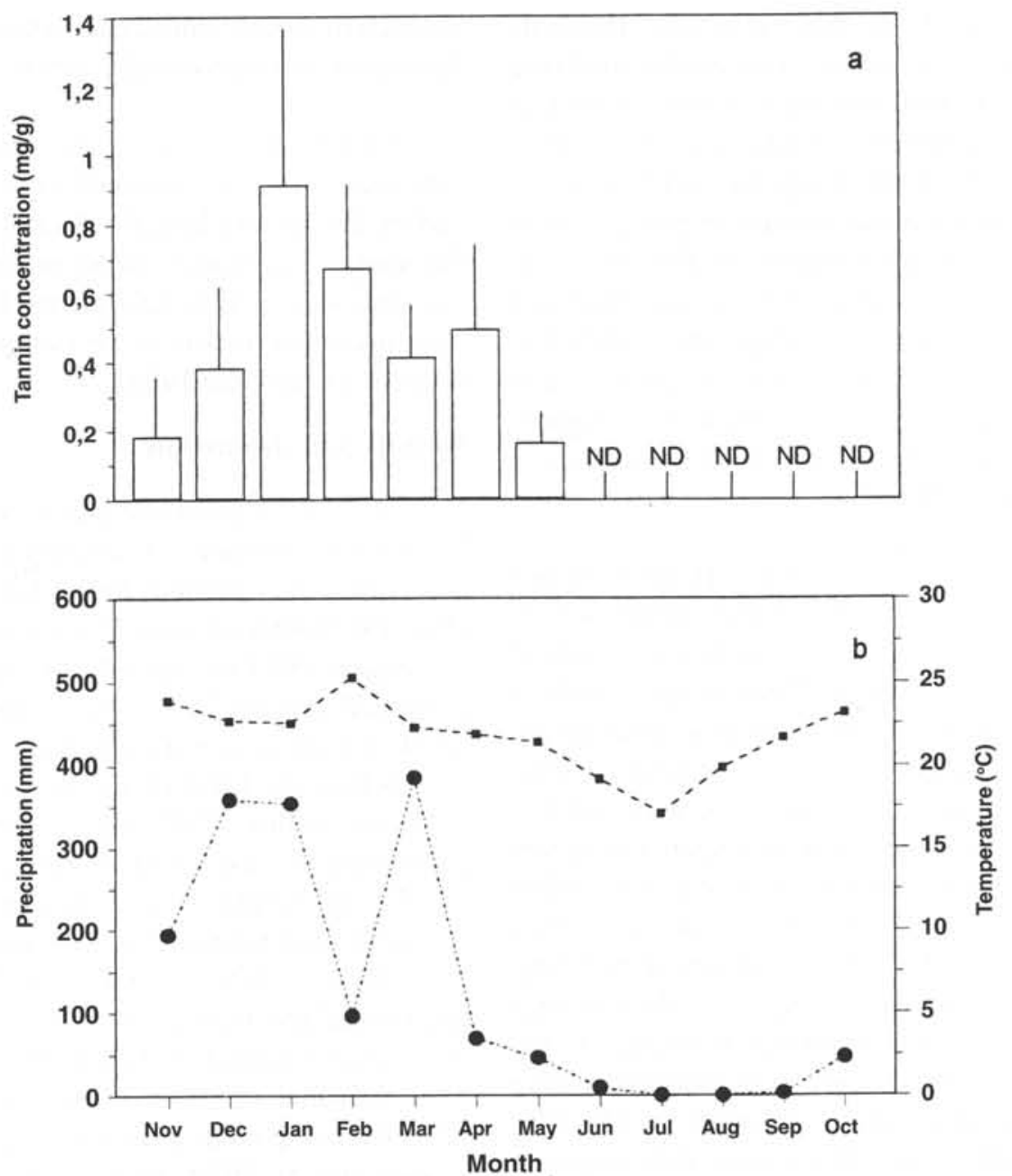

Figure 1. (a) Average tannin concentration ( \pm SE) in leaves of Baccharis dracunculifolia from November/1993 to October/1994. ND, not detectable using the radial diffusion method; (b) Monthly average temperature (filled squares) and monthly average precipitation (filled circles) from November/1993 to October/1994.

is likely that an increased intensity and duration of light incidence during the summer may induce a higher production of tannins in B. dracunculifolia throughout this period, although these seasonal climatic differences are not very marked in the tropics (Ricklefs 1990). In addition, the reproductive period of this species is usually during November and December, and from March to June (Espírito-Santo \& Fernandes 1998), coincident with periods of higher water availability and tannin production. Thus, it is possible that the plant is unable to sustain growth and reproduction at the same time, even under suitable environ- mental conditions. In this case, plants would use the available nutrients for reproductive structures, with the accumulating carbon being allocated to phenolic compounds (Herms \& Mattson 1992).

Tannins were not detected in the studied plants during the winter, when water availability was low (four months with no rainfall). Under moderate drought, growth is reduced more than photosynthesis, and any excess carbon remaining in leaves is available for the production of secondary compounds (Gershenzon 1984; Herms \& Mattson 1992). However, periods of severe drought may preclude either carbon production or phenolic 
biosynthesis, as a consequence of a limitation in photosynthetic enzymes available for carbohydrate production or a reduction in the activity of the enzymes involved in phenolic biosynthesis (Gershenzon 1984). For B. dracunculifolia, it seems that the decline in water availability from May to June was sufficient to expose the plants to a severe drought, drastically reducing tannin production. Furthermore, the incidence of solar UV-B radiation is lower during the winter, which would also reduce tannin production (Mole et al. 1988; Rozema et al. 1997). Nevertheless, further studies are needed to experimentally evaluate the effects of light intensity and plant phenology on tannin production.
Water availability - Tannin concentration varied markedly on both control and irrigated treatments, but did not show any pattern by the $69^{\text {th }}$ day after the end of the irrigation experiment (Fig. 2a). No significant differences were observed between the irrigated and control treatments on five out of seven measurements (Tab. 1). Relative rates of shoot growth also varied during the study period, but with no apparent trends (Fig. 2b). There were no statistical differences between treatments on four out of six intervals analysed (Tab. 2). These results suggest that irrigation was not sufficient to produce an effective response by the plant, probably because of other factors, such as light incidence or nutrient availability, which may also affect the plant traits analysed in this study.
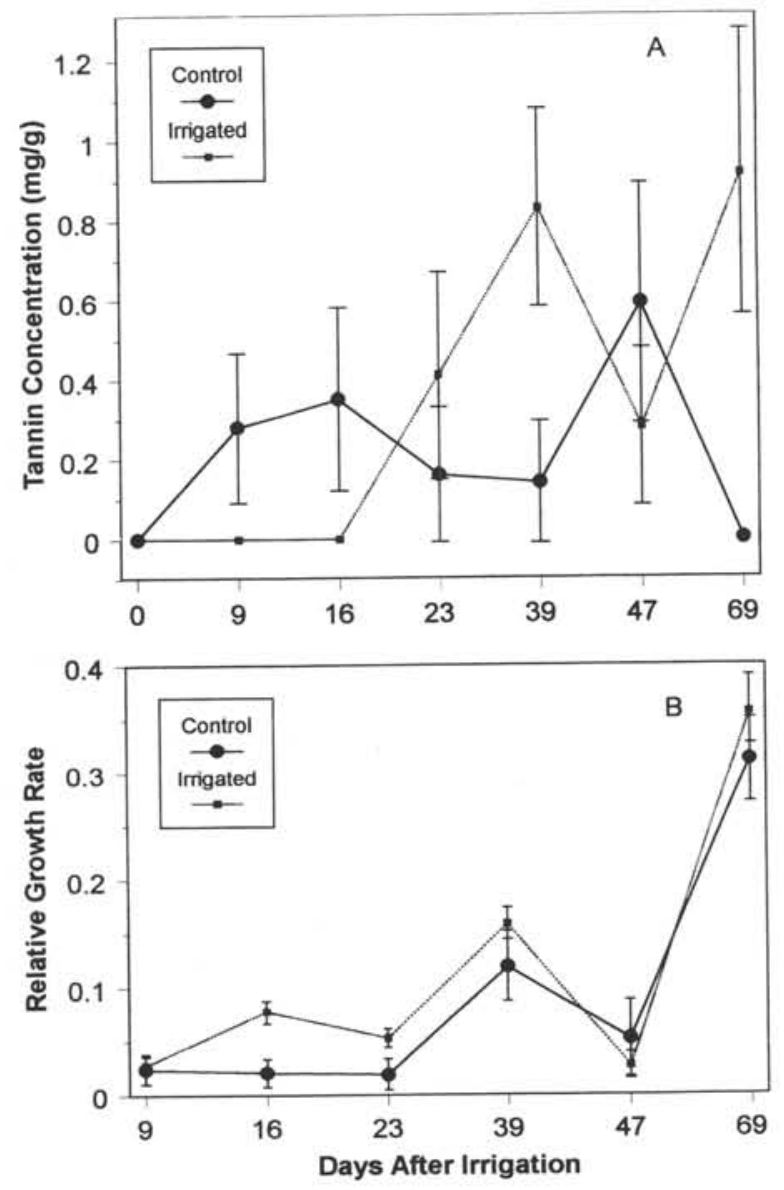

Figure 2. (a) Average tannin concentration ( \pm SE) in leaves of Baccharis dracunculifolia in control and irrigated treatments on seven intervals after the end of the irrigation experiment; (b) Average relative growth rate of shoots of Baccharis dracunculifolia in control and irrigated treatments on six intervals after the end of irrigation treatment. 
Table 1. Mann-Whitney U test statistics for tannin concentration between control and irrigated treatments. ns: not significant at a $=0.05(\mathrm{n}=20$ on each interval).

\begin{tabular}{ccc}
\hline Interval (days) & $\mathrm{U}$ & $\mathrm{P}$ \\
\hline 0 & 50.0 & $\mathrm{~ns}$ \\
9 & 60.0 & $\mathrm{~ns}$ \\
16 & 60.0 & $\mathrm{~ns}$ \\
23 & 44.0 & $\mathrm{~ns}$ \\
39 & 25.0 & $<0.05$ \\
447 & 61.0 & $\mathrm{~ns}$ \\
69 & 30.0 & $<0.05$ \\
\hline
\end{tabular}

Table 2. Mann-Whitney U test statistics for relative shoot growth rate between control and irrigated treatments. ns: not significant at $\mathrm{a}=0.05(\mathrm{n}=200$ on each interval).

\begin{tabular}{crc}
\hline Interval (days) & $\mathrm{U}$ & $\mathrm{P}$ \\
\hline 9 & 41.0 & $\mathrm{~ns}$ \\
16 & 2.0 & $<0.05$ \\
23 & 0 & $<0.05$ \\
39 & 33.0 & $\mathrm{~ns}$ \\
47 & 60.0 & $\mathrm{~ns}$ \\
69 & 45.0 & $\mathrm{~ns}$ \\
\hline
\end{tabular}

Although tannin concentration in the plants used in the study of seasonal variation was not detectable during the winter, plants used in the irrigation experiment presented these compounds in both treatments. The production of tannins may occur during the winter, if plants are subjected to a moderate drought (Gershenzon 1984). Furthermore, Esau (1959) and Fahn (1990) outlined the role of tannins in protecting the plant against dehydration, since these compounds apparently hinder the passage of water from the cells around the plant veins under drought conditions (Fahn 1990). Thus, tannin production by $B$. dracunculifolia during the dry season may be worthwhile. In the irrigation experiment, tannins were not expected in the control plants, since these compounds were not detected in plants used in the seasonal study at the same period of time. This may result from differences in individual plant responses in adjusting to moisture availability and a toleration to drought (Horner 1990; Louda \& Collinge 1992). Differences in individual responses to environmental conditions were reported in several studies (Moran 1981; Jonasson et al. 1986; McCrea \& Abrahamson
Table 3. Spearman correlation coefficients between relative shoot growth and tannin concentration on each interval for control and irrigated treatments $(\mathrm{n}=10$ on each interval).

\begin{tabular}{|c|c|c|}
\hline \multirow[t]{2}{*}{ Interval (days) } & \multicolumn{2}{|c|}{ Treatment } \\
\hline & Control & Irrigated \\
\hline 9 & - & - \\
\hline 16 & -0.16 & - \\
\hline 23 & 0.07 & - \\
\hline 39 & -0.06 & -0.20 \\
\hline 47 & -0.17 & -0.29 \\
\hline 69 & 0.18 & -0.16 \\
\hline
\end{tabular}

1987), as a consequence of plant genotype and microsite differences in density, soil and moisture regimes (Kearsley \& Whitham 1989). Thus, the production of tannins by some individuals of $B$. dracunculifolia during the winter may possibly occur as a result of differences in microhabitat suitability and plant genetics.

There were no strong relationships between the relative shoot growth rate and tannin concentration in the control treatment (Tab. 3, Fig. 2a and $2 \mathrm{~b}$ ). At three intervals, the relationship between these variables was negative, and positive at two other (at one interval none of the plants produced tannins). In the irrigated treatment, the relationship between the relative shoot growth rate and tannin concentration was negative at three intervals on which plants presented tannins (Tab. 3). These results suggest a trade-off between tannin production and the allocation of the available carbon to shoot growth. As photosynthetic rates are decreased during the winter as a consequence of a water and light shortage (Mole et al. 1988), the limited carbon may be allocated alternately to tannin production or shoot growth. However, Corcoran et al. (1972) demonstrated that tannins also act as gibberellin antagonists, regulating plant growth. Thus, the negative correlation between tannin concentration and shoot growth observed for $B$. dracunculifolia may be a result of the inhibitory effects of tannins in the gibberellininduced growth (Corcoran et al. 1972).

Gender differences - There were no significant differences in tannin concentration between male and female plants of $B$. dracunculifolia $(\mathrm{t}=$ $1.004, \mathrm{n}=120, \mathrm{p}>0.05)$. Male individuals had 
an average of $0.285 \pm 0.116 \mathrm{mg} / \mathrm{g}$ of tannins $(\mathrm{n}=$ 60 ), while average tannin concentration in the leaves of female individuals was $0.332 \pm 0.180$ $\mathrm{mg} / \mathrm{g}(\mathrm{n}=60)$. This lack of sexual differences on tannin concentration corroborates a recent study performed with the same species (Espírito-Santo \& Fernandes 1998). Araújo et al. (1995) also did not find intersexual differences in $B$. dracunculifolia for other plant traits, such as height, crown and basal area. Furthermore, Ahman (1997) showed that the reproduction investment may be higher in male rather than female individuals in certain dioecious species, inverting the allocation pattern predicted in the carbon-nitrogen balance hypothesis (Herms \& Mattson 1992). Thus, further studies on the reproductive biology of B. dracunculifolia are necessary to explain the absence of differences influenced by plant sex in resource allocation.

Tannins may play various different functions in plant metabolism, and the demand for these compounds may be determined by several complex plant responses. Tannin production in $B$. dracunculifolia does not seem to be affected solely by water availability, but rather by an interaction of multiple factors, related to plant phenology and energetic balance, and seasonal variations in other environmental conditions.

\section{Acknowledgments}

We are very grateful to SJG Alvim, ESA Marques, and two anonymous reviewers for their critical comments on the early versions of this manuscript. The Pampulha Airport provided the climatic data used in this study. This project was supported by CNPq, FAPEMIG and IFS.

\section{References}

Ahman, I. 1997. Growth, herbivory and disease in relation to gender in Salix viminalis L. Oecologia 111: 61-68.

Araújo, A. M.; Fernandes, G. W. \& Bedê, L. C. 1995. Influência do sexo e fenologia de Baccharis dracunculifolia DC. (Asteraceae) sobre insetos herbívoros. Revista Brasileira de Entomologia 39: 347-353.

Bryant, J. P.; Chapin III, F. S. \& Klein, D. R. 1983. Carbon/ nutrient balance of boreal plants in relation to vertebrate herbivory. Oikos 40: 357-368.

Coley, P. D. \& Barone, J. A. 1996. Herbivory and plant defenses in tropical forests. Annual Review of Ecology and Systematics 27: 305-335.
Corcoran, M. R.; Geissman, T. A. \& Phinney, B. O. 1972. Tannins as gibberellin antagonists. Plant Physiology 49: 323-330.

Esau, K. 1959. Anatomia Vegetal. Omega, Barcelona.

Espírito-Santo, M. M. \& Fernandes, G. W. 1998. Abundance of Neopelma baccharidis (Homoptera: Psyllidae) galls on the dioecious shrub Baccharis dracunculifolia (Asteraceae). Environmental Entomology 27: 870-876.

Faeth, S. H. 1992. Do defoliation and subsequent phytochemical responses reduce future herbivory on oak trees? Journal of Chemical Ecology 18: 915-925.

Fahn, A. 1990. Plant Anatomy. Pergamon, Oxford.

Feeny, P. P. 1970. Seasonal changes in oak leaf tannins and nutrients as a cause of spring feeding by winter moth caterpillars. Ecology 51: 565-581.

Ferrari, J. M. 1977. Vegetação do câmpus da Universidade Federal de Minas Gerais. Oréades 6: 3-5.

Gershenzon, J. 1984. Changes in the level of plant secondary metabolites under water and nutrient stress. Recent Advances in Phytochemistry 18: 273-320.

Hagerman, A. E. 1987. Radial diffusion method for determining tannin in plant extracts. Journal of Chemical Ecology 13: 437-449.

Herms, D. A. \& Mattson, W. J. 1992. The dilemma of plants: to grow or defend. The Quarterly Review of Biology 67: 283-352.

Horner, J. D. 1990. Nonlinear effects of water deficits on foliar tannin concentration. Biochemical Systematics and Ecology 18: 211-213.

Jing, S. W. \& Coley, P. D. 1990. Dioecy and herbivory: the effect of growth rate on plant defense in Acer negundo. Oikos 58: 369-377.

Jonasson, S.; Bryant, J. P.; Chapin, F. S. \& Anderson, M. 1986. Plant phenols and nutrients in relation to variations in climate and rodent grazing. American Naturalist 128: 394-408.

Kearsley, M. J. C. \& Whitham, T. G. 1989. Developmental changes in resistance to herbivory: implications for individuals and populations. Ecology 70: 422-434.

Krischik, V. A. \& Denno, R. F. 1990. Patterns of growth, reproduction, defense and herbivore in the dioecious shrub Baccharis halimifolia (Compositae). Oecologia 83: 182190.

Louda, S. M. \& Collinge, S. K. 1992. Plant resistance to insect herbivores: a field test of the environmental stress hypothesis. Ecology 73: 153-169.

McCrea, K. D. \& Abrahamson, W. G. 1987. Variation in herbivore infestation: historical vs. genetic factors. Ecology 68: 822-827.

Mole, S.; Ross, J. A. M. \& Waterman, P. G. 1988. Lightinduced variation in phenolic levels in foliage of rainforest plants. I. Chemical changes. Journal of Chemical Ecology 14: 1-21.

Moran, N. 1981. Intraspecific variability in herbivore performance and host quality: a field study of Uroleucon caligatum (Homoptera: Aphididae) and its Solidago hosts (Asteraceae). Ecological Entomology 6: 301-306.

Rhoades, D. F. \& Cates, R. G. 1976. Toward a general theory of plant antiherbivory chemistry. Recent Advances in Phytochemistry 10: 168-213. 
Ricklefs, R. E. 1990. Ecology. W. H. Freeman \& Company, New York.

Rozema, J.; van de Staaij, J.; Björn, L. O. \& Caldwell, M. 1997. UV-B as an environmental factor in plant life: stress and regulation. Trends in Ecology and Evolution 12: 22-28.

Sagers, C. L. \& Coley, P. D. 1995. Benefits and costs of defense in a neotropical shrub. Ecology 76: 1835-1843.

Salatino, A.; Kraus, J. E. \& Salatino, M. L. F. 1993. Contents of tannins and their histological localization in young and adult parts of Struthanthus vulgaris Mart. (Loranthaceae). Annals of Botany 72: 409-414.
Shure, D. J.; Mooreside, P. D. \& Ogle, S. M. 1998. Rainfall effects on plant-herbivore processes in an upland oak forest. Ecology 79: 604-617.

Swain, T. 1979. Tannins and lignins. Pp 557-682. In: G. A. Rosenthal \& D. H. Janzen (Eds.), Herbivores: their interactions with secondary plant metabolites. Plenum, New York.

Zar, J. H. 1996. Biostatistical analysis. Prentice-Hall, Englewood Cliffs, New Jersey. 